\title{
РЕЦЕНЗИИ REVIEW
}

УДК $130.3 ; 82-3 ; 82-4$

DOI 10.18413/2075-4566-2019-44-1-181-185

\author{
ВРЕМЯ ДУХОВНОЙ РАДОСТИ: \\ РЕЦЕНЗИЯ НА КНИГУ В.П. РИМСКОГО «ДНИ ПЕЧАЛИ И СКОРБИ» \\ TIME OF SPIRITUAL JOY: \\ BOOK REVIEW BY V.P. RIMSKOGO "DAYS OF SORROW AND GRIEF".
}

\author{
А.А. Трунов \\ A.A. Trunov \\ Белгородский университет кооперации, экономики и права, \\ Россия, 308023, Белгород, Садовая, $116 \mathrm{a}$ \\ Belgorod University of Cooperation, Economics \& Law \\ 116a Sadovaya St, Belgorod, 308023, Russia \\ E-mail: trunovv2013@yandex.ru
}

\begin{abstract}
Аннотация
В рецензии дана литературоведческая и философская интерпретация художественной прозы и эссеистики русского философа и писателя В.П. Римского. В.П. Римский интуитивно тяготеет к актуализации собственного биографического мифа, выраженного иносказательным языком притчи или псалма. В его главных литературных и философских произведениях представлена не только вполне конкретная и реалистичная история духовных исканий, успехов и неудач отдельной рефлексирующей личности, но и обобщённая интеллектуальная биография всего послевоенного поколения. В творчестве В.П. Римского органично сплетаются индивидуальная и народная судьба, образы отца, матери, жизни, смерти, предательства, чести, любви, дружбы, малой и большой истории. Тема покаяния и преодоления смерти через обращения к Источнику Жизни также является важной для понимания философских и художественных произведений автора.
\end{abstract}

\section{Abstract}

The review presents the literary and philosophical interpretation of prose and essays of the Russian philosopher and writer V.P. Rimskiy, presented in his new book of prose and essay. V.P. Rimskiy, intuitively tends to actualize his own biographical myth, expressed in the allegorical language of the parable or psalm. His main literary and philosophical works present not only a very concrete and realistic history of spiritual searches, successes and failures of an individual reflective personality, but also a generalized intellectual biography of the entire postwar generation. In the works of V.P. Rimskiy organically interwoven individual and national destiny, images of father, mother, homeland, life, death, betrayal, honor, love, friendship, small and big history. The theme of repentance and overcoming death through reference to the Source of Life is also important for understanding the philosophical and artistic works of this author.

Ключевые слова: В.П. Римский, философская проза, русская философия, литература, культура, смыслы бытия, правда жизни.

Keywords: V.P. Rimskiy, philosophical prose, Russian philosophy, literature, culture, the meaning of life, the truth of life. 
Выход в свет новой великолепно иллюстрированной книги известного философа и писателя В.П. Римского «Дни печали и скорби» [Римский, 2017], в которой под одной обложкой собраны написанные им в разные годы повести, рассказы и эссе, я воспринимаю как значимое событие духовной и интеллектуальной жизни как минимум нескольких регионов, а если принять во внимание востребованность профессора В.П. Римского в качестве культуролога и религиоведа, то и России в целом.

Традиция фундаментального осмысления человеческих проблем в художественной прозе восходит ещё к Платону и другим мыслителям первой величины. И хотя русские писатели-классики (Л.Н. Толстой, Ф.М. Достоевский, А.П. Чехов, А.М. Горький) поднимали в своём творчестве наиболее существенные философские вопросы, которые не имеют, да и не могут иметь простых и обывательских ответов, следует иметь в виду, что встречное движение философов в большую литературу было скорее исключением, нежели правилом. Из заслуживающих внимания примеров приходят на ум попытки А.С. Хомякова, В.С. Соловьёва, А.Ф. Лосева, М.К. Петрова и особенно А.А. Зиновьева. Но всё-таки эти замечательные люди, при всей их гениальности и одарённости, воспринимаются нами в первую очередь как философы и лишь во вторую - как писатели. Баланс философии и литературы здесь нарушается исключительно в пользу философии, что не мешает этим авторам облекать свои мысли в литературную форму.

Тем и ценно творчество В.П. Римского, в котором философия тесно переплетается с литературой, а литература - с философией. Одно здесь настолько неотделимо от другого, что трудно сказать, где философская мысль оборачивается впечатляющей игрой тонких аллюзий и художественных образов, которые воздействуют на читателя с архетипической мощью и полнотой, а где наоборот, - литература плавно «перетекает» в философию, обогашая её новым пониманием быта и бытия, правды жизни и духовного опыта человека.

В.П. Римский - это настоящий реактор смыслов, всегда опережающих научный мейнстрим. Когда он охвачен какой-либо трудноразрешимой идеей, его мысль невозможно сбить с толку или остановить. И в этой ситуации самое лучшее, что может сделать собеседник В.П. Римского, - это слушать и запоминать, поскольку именно в процессе таких творческих озарений проговаривается и выговаривается самое главное. «Что нам приоткрывает истина в просвете бытия?» - таков, быть может, главный вопрос, который рассматривает В.П. Римский [Римский, 2017, с. 494]. По его же словам, «философия никогда не бывает неким ожидаемым рассветом, а всегда не просто поиск впотьмах, в зазоре истины и бытия, но и жизнь на грани смерти, на рубеже тьмы и света, свободы и нормативности. Философия - всегда в ситуации выбора между свободой и принуждением» [Римский, 2017 , с. 494]. Примерно то же самое можно сказать и о литературе, которая в жизни В.П. Римского играет никак не менее важную роль, чем философия.

Помимо того, что В.П. Римский является крупным исследователем мифологического и религиозного сознания, включая их превращённые формы, складывается впечатление, что он интуитивно тяготеет к актуализации собственного биографического мифа, выраженного иносказательным языком притчи или псалма. Ведь если внимательно вчитаться в его главные литературные и философские произведения, то перед нами предстанет не только вполне конкретная и реалистичная история духовных исканий, успехов и неудач отдельной рефлексирующей личности, но и своеобразная обобщённая биография всего поколения, родившегося через десять лет после Победы, заставшего Оттепель и Застой, вступившего в пору социальной и интеллектуальной зрелости в период Перестройки, перешагнувшего рубеж тысячелетий и являющегося носителем великих культурных и интеллектуальных традиций, соединяющих Восток и Запад, русское и советское, Традицию, Модерн и Постмодерн. Здесь органично сплетаются индивидуальная и народная судьба, из бессознательных ментальных глубин воспаряют и кристаллизируются в текстах художественных произведений образы отца, матери, Родины, жизни, смерти, предательства, чести, любви, дружбы, малой и большой истории. 
Не случайно эпиграфом ко всей книге являются слова псалмопевца царя Давида о бренном и вечном: «Но Бог избавит душу мою от власти преисподней, когда примет меня) (Пс. 48: 16). Этот лейтмотив волевого усилия и сознательного отказа от греха, абсолютной честности и безжалостности к себе, исправления и изменения жизненной колеи является важнейшим для понимания не только концепции данной книги, но и всего литературного и философского творчества В.П. Римского.

Книга открывается повестью «Нонконформисты» [Римский, 2017, с. 8-121]. Вкратце её сюжет таков: молодой человек приехал в большой город, неизбежно возникли трудности социализации, встал вопрос о цене, которую он готов или не готов заплатить за то, чтобы приобщиться к реальным или условным благам «цивилизованной» жизни. Трагическое переживание разрыва с родными, одиночество в толпе, неприятие мещанства и голод на смыслы. Подпольная жизнь, которая противопоставляется показному лицемерию и подловатой двусмысленности официоза. Столкновение характеров. Нонконформизм. Благородство и подончество. Блеск и нищета богемно-диссидентского движения. Ощущение застоя и жажда перемен. Бунт нонконформистов против репрессивных практик охранительства. Быть или казаться? Одновременно это исполненный горечи рассказ о том, как Система ломает и калечит людей, предлагая им мнимое благополучие ценой отказа от идеалов. В повести показаны острые конфликты, которые происходят не только между отцами и детьми, но и внутри одного поколения, представители которого пытаются найти себя в предлагаемых обстоятельствах.

Повесть «Богатяновка: Семидесятые» [Римский, 2017, с. 123-191] продолжает заявленную тему. Она ценна не только реалистическим описанием студенческой жизни 70-х гг. прошлого века, глубоким психологизмом, исключительной точностью деталей, образами героев, мягким юмором, сочетанием возвышенного и приземлённого, но и своей главной сюжетной линией. Истории, рассказанные автором, великолепно дополняют друг друга. В результате получается удивительно интересное произведение, позволяющее лучше понять это замечательное поколение: живое, ироничное, устремлённое в будущее, питающее склонность к самоанализу и иронии. В этих художественных зарисовках великолепно показаны образы времени, места и разноплановые характеры. Повесть полностью разрушает привычный миф о Застое, обнажая мощное глубинное движение молодых и тянущихся к духовности и правде молодых людей, которые перестали реагировать на уловки пропаганды и стали жить полноценной жизнью.

Повесть «Провал» [Римский, 2017, с. 192-325], которая занимает большое место в данной книге, можно рассматривать с разных позиций. Она - о власти и «культе личности), «подпольном человеке» и экзистенциальном бунте, культуре и антикультуре, а также о специфических неурядицах русской и позднесоветской интеллигенции, например, о её нарциссизме, склонности к болтовне и хронической неспособности к самоорганизации. Только героем повести является не чистый юноша, столкнувшийся с соблазнами взрослой жизни, как это происходит в «Нонкорфомистах» или «Богатяновке», а зрелый мужчина, кандидат наук и матёрый преподаватель, пользующийся заслуженным уважением и любовью студентов. Это сильный, обаятельный и стойкий человек, который однажды восстал против несправедливости и маразма задушевной (то ли душат, то ли не чают души?) репрессивности унылой и предсказуемо несчастливой кафедральной жизни, где участие соседствует с доносом, поддержка - с завистью, а талант - с желанием его уничтожить.

Как герои, так и антигерои «Провала» имеют реальных прототипов. Однако автор абстрагировался от личных симпатий или антипатий и создал целостное и законченное художественное произведение, которое с полным основанием можно назвать пророческим. Здесь нет манихейского деления на «правильных» и «неправильных», представителей света и тьмы. «Провал» буквально соткан из тонких антиномий и диалектических переходов. Блестящее владение приёмами психоанализа позволяет В.П. Римскому показать внутренний мир героев, их интересы, ценности, заботы, переживания. У кого-то они - о самореализации и смысле жизни, а у кого-то - о чечевичной похлёбке мнимого мещанско- 
го благополучия и потребительского изобилия, например, о модном детективе или вкусном борще. Тонкая ирония и мягкий юмор здесь сочитаются с острой и весьма жёстской полемикой, направленной на поиски и отстаивание жизненной правды. Пронзительно и точно звучат темы предательства и самоотказа, готовности или неготовности интеллигента публично отстаивать свои ценности и идеалы, принимать или не принимать позицию репрессивной и отчуждённой от реального человека Системы, которая стремится к бюрократизации всех сторон научной и преподавательской деятельности, поощряя приспособленчество, начётничество, серость и двоемыслие. Самое страшное в этой ситуации - оказаться 《своим среди чужих и чужим среди своих», что и происходит с одним из героев.

Не менее интересны искромётные диалоги, в которых сталкиваются конфликтующие системы ценностей, различные парадигмы общественного устройства, идеологии и стратегии успеха. Здесь представлены либералы и консерваторы, охранители и ретрограды, молодые и зрелые. И все они живут, отстаивают своё видение правды, пытаются изменить ситуацию к лучшему или не желают покидать зону комфорта. Голос автора растворён в этой палитре мнений, но к нему обязательно нужно прислушаться.

Одновременно с этим «Провал» - это важный исторический и культурологический текст, позволяющий анализировать механизмы возникновения Перестройки и выявлять роль интеллектуалов в ней. Поэтому повесть читается как никогда актуально. В ней нет привычных атрибутов постмодернистского дискурса, но имеется нечто гораздо более существенное: внутренняя раскованность, творческая свобода и человеческое достоинство, столь ствойственные главным произведениям классической литературы.

«Провал» интересен ещё и своими нереализованными смысловыми и социальными альтернативами: ведь «лихие» 90-е и стабильно безликие нулевые, могли бы и не состояться. И то, что мы сегодня возвращаемся к ситуации Перестройки, заставляет нас заново осмыслить повесть В.П. Римского, в которой показаны процессы дряхления и загнивания впавшей в маразм охранительной системы, обмещанивания быта и бытия, а также очень точно проанализировано мировоззрение глубинньх типов русской и советской интеллигенции. Статегические ориентиры гуманитарного экспертного сообщества здесь также показаны весьма репрезентативно [Трунов, 2017]. Спор, который столь ожесточённо ведут между собой герои «Провала», до сих пор не окончен.

Большую художественную ценность представляют рассказы Виктора Павловича, в которых присутствуют семейные предания, детские травмы и юношеские впечатления, опыт преодоления внутриличностных и межличностных конфликтов («Предание», «Полтинник», «Беженка» [Римский, 2017, с. 332-354]) Здесь В.П. Римский раскрывается уже не как привычный для многих рафинированный интеллектуал, а как носитель глубинных, почвенных традиций. Сквозной для произведений В.П. Римского является тема, связанная с памятью, Родиной и семьёй, историей рода, в которой преломляется история народа, мотивы примирения с Отцом, евангельский образ блудного сына. Детские воспоминания приобретают архетипическую мощь и облекаются в форму литературных произведений, в которых присутсвуют несколько планов. Так, в рассказе «Адамов грех» В.П. Римский обращается к преодолению травмирующих детских воспоминаний [Римский, 2017, c. 365-370]. Весьма глубок и интересен рассказ «Спроси у отца» [Римский, 2017, c. 380-391], в котором задолго до Дж. Агамбена [Агамбен, 2011] намечается тема «священнопроклятых», трагической изломанности русской судьбы и её неподсудности.

Рассказ «Не без греха» [Римский, 2017, с. 406-414] можно рассматривать как опыт серьёзной духовной работы по избавлению от весьма распространённых среди наёмных работников умственного труда недугов плоти и страждушего духа. Автор не просто описывает собственный жизненный опыт, а через художественную прозу показывает реальные способы конструктивного решения важнейших психологических проблем, с которыми сталкиваются современные интеллигенты, измученные хроническим безденежьем, бытовой неустроенностью и задавленные тисками бюрократического контроля. 
Тема покаяния, метанойи, отсечения греха и преодоление смерти через обращения к Источнику Жизни проходит через всю данную книгу, находя своё наиболее сильное воплощение в рассказе «Дни печали и скорби» [Римский, 2017, с. 391-402]. По своему воздействию этот рассказ можно поставить в один ряд со «Смертью Ивана Ильича» Л.Н. Толстого. Сходство имён и трагически-реалистичное описание смерти главного героя как очищения через неизлечимую болезнь и страдание делает этот рассказ смысловым центром всей книги («Он с тоской почувствовал, как мало пожил, что там, в глубине души и тела, ещё есть силы» [Римский, 2017, с. 395]). Поразительнее всего именно то, что этот рассказ был написан весьма молодым человеком, который отнюдь не спасовал перед вызовом страшной и серьёзной темы. Мысли автора глубоки, а язык исключительно точен и необыкновенно богат.

Характеризуя творчество Римского-писателя, самое время вернуться к теме Римскогофилософа. Всё, о чём пишет В.П. Римский, является результатом глубоких и серьёзньх раздумий о времени и о себе. Тем интереснее его эссе, представляющие собой развёрнутые авторские высказывания, которые позволяют нам лучше понять творческий метод незаурядного мыслителя. Перечитывая его эссе о рекламном мифе [Римский, 2017, с. 418-423], метаморфозах тоталитаризма [Римский, 2017, с. 423-444], Православии и русской культуре в XXI веке [Римский, 2017, с. 444-460], отложенных кризисах этноидентичности в современной России [Римский, 2017, с. 460-473], матрице русофобии и ментально-антропологических типах интеллигенции [Римский, 2017, с. 473-494], я ловил себя на мысли о том, как верно и точно выразил автор «дух времени», заложив основы будущих монографий и диссертаций. Например, в «Одиноком баркасе Михаила Петрова» [Римский, 2017, с. 504-517] В.П. Римский намечает оригинальную программу философско-культурологического исследования творчества этого выдающегося мыслителя, что позволило ему в дальнейшем вывести «петрововедение» из своеобразного теоретического и методологического тупика [Учреждающая дискурсивность..., 2017]. Не менее содержательным представляется эссе «Нагая живая жизнь Варлама Шаламова» [Римский, 2017, с. 522-545].

Экзистенциальное и социальное, мистическое и рациональное, бренное и вечное, постоянная рефлексия и способность воспарить над обыденностью, устремлённость вперёд, полемический талант, неустранимое свободомыслие, любовь к Жизни - таковы наиболее интересные свойства В. П. Римского - писателя и философа: диалектика, правдоискателя, стремящегося к правде и абсолютной честности перед самим собой. И хотя книга называется «Дни печали и скорби», для меня дни, потраченные на её прочтение и осмысление, стали временем настоящей духовной радости. Это качественная литература и философия, которые насыщают нашу жизнь евангельскими смыслами, заставляют задуматься о покаянии, попытаться с помощью Божией изменить себя и припасть к источнику Жизни. Перед нами - интересная, глубокая и достойная книга.

\section{Список литературы References}

1. Агамбен, Дж. Ното sacer. Суверенная власть и голая жизнь. М.: Европа, 2011. -256 с.

Agamben, G. Homo sacer. Sovereign power and naked life. M.: Europe, 2011. 256 p.

2. Римский, В.П. Дни печали и скорби: повести, рассказы, эссе. М.: Летний сад, 2017. 556 с.

Rimskiy, V.P. Days of sorrow and grief. M.: Letniy sad, 2017. 556 p.

3. Трунов, А.А. Стратегические ориентиры развития гуманитарного экспертного сообщества. Философские науки. 2017. № 4. С. 81-88.

Trunov, A.A. Strategic Guidelines for Development of Humanitarian Expert Community. In: Philosophical Sciences. 2017. Vol. 4,pp. 81-88.

4. Учреждающая дискурсивность Михаила Петрова: интеллектуал в интерьере культурного капитала / под ред. В.П. Римского. М.: Канон+ РОИР «Реабилитация», 2017. 456 с.

Mikhail Petrov's founding discursiveness: an intellectual in the interior of cultural capital / ed. V.P. Rimskiy. M.: Canon + ROIR "Rehabilitation", 2017. 456 p. 